\title{
Carbenicillin and Penicillin G Inhibit Platelet Function In Vitro by Impairing the Interaction of Agonists with the Platelet Surface
}

\author{
Sanford J. Shattil, Joel S. Bennett, Margaret McDonough, and Judy \\ TuRnBull, Hematology-Oncology Section, Department of Medicine, \\ University of Pennsylvania School of Medicine and the Philadelphia \\ Veterans Administration Hospital, Philadelphia, Pennsylvania 19104
}

\begin{abstract}
A B S T RACT Carbenicillin or penicillin G administered in large doses can cause a bleeding diathesis as a result of platelet dysfunction. These antibiotics also inhibit platelet aggregation in vitro, although several-fold larger concentrations of drug are required to demonstrate this effect. We wondered whether these antibiotics might impair platelet function by interfering with the initial step of platelet activation: the binding of agonists to their specific receptors on the platelet surface.
\end{abstract}

Platelet aggregation and $\left[{ }^{14} \mathrm{C}\right]$ serotonin release induced by epinephrine were competitively inhibited by carbenicillin and penicillin $G$ in vitro. At antibiotic concentrations that inhibited platelet function by more than $80 \%$, the affinity of platelet $\alpha$-adrenergic receptors for the $\alpha$-adrenergic antagonist, $\left[{ }^{3} \mathrm{H}\right]$ dihydroergocryptine, and for epinephrine was reduced twofold by carbenicillin and sixfold by penicillin $\mathrm{G}(P<0.01)$. Platelet aggregation and $\left[{ }^{14} \mathrm{C}\right]$ serotonin release stimulated by ADP were also competitively inhibited by these antibiotics. In addition, carbenicillin reduced the incorporation of an ADP affinity label, 5'-p-fluorosulfonylbenzoyl $\left[{ }^{3} \mathrm{H}\right]$ adenosine, into its binding protein in platelet membranes. Moreover, both carbenicillin and penicillin G impaired the interaction of von Willebrand factor with platelets as evidenced by their inhibition of the agglutination of formalin-fixed platelets by ristocetin, snake venom, or bovine factor VIII.

These studies demonstrate that carbenicillin and penicillin $\mathrm{G}$ inhibit platelet function in vitro by im-

This work was presented in part at the annual meeting of the American Federation for Clinical Research, Washington, D. C., May 1979. Clin. Res. 27: 306A. (Abstr.)

Dr. Shattil is a Clinical Investigator of the U. S. Veterans Administration. Address reprint requests to Dr. Shattil.

Received for publication 13 June 1979 and in revised form

5 October 1979. pairing the interaction of several agonists with their specific receptors on the platelet surface membrane. If this were mechanism operative in vivo, it could account for the hemorrhagic as well as the potential antithrombotic effects of these antibiotics.

\section{INTRODUCTION}

Large doses of the antibiotics, carbenicillin, and penicillin G, can cause a bleeding diathesis in patients $(1,2)$. These drugs presumably do so by impairing platelet function because they prolong the bleeding time of human volunteers $(3,4)$. Moreover, platelets from individuals taking these antibiotics aggregate poorly in response to several aggregating agents $(3,4)$ and they agglutinate poorly in response to ristocetin (2). Platelets incubated with carbenicillin or penicillin $G$ in vitro also respond poorly to a variety of platelet agonists, although larger concentrations of antibiotic are required to demonstrate this effect (5). The mechanism by which these antibiotics impair platelet function is unknown.

Platelet adhesion, aggregation and secretion are initiated by the binding of agonists to their specific receptors on the platelet membrane $(6,7)$. We wondered, therefore, whether carbenicillin or penicillin $\mathrm{G}$ might inhibit platelets in vitro by interfering with the binding of agonists to the platelet surface. We studied two agonists for platelet aggregation, epinephrine, and ADP, as well as the plasma protein, von Willebrand factor, which participates in the adhesion of platelets to the vascular subendothelium (8). Epinephrineinduced platelet function is an $\alpha$-adrenergic event (9, 10). Therefore, platelet $\alpha$-adrenergic receptors were studied by measuring the binding of the alpha adrenergic antagonist, $\left[{ }^{3} \mathrm{H}\right]$ dihydroergocryptine, to platelets (11). ADP binding was assessed by measuring the covalent incorporation of an ADP affinity analogue, 5'-p-fluoro- 
sulfonylbenzoyl $\left[{ }^{3} \mathrm{H}\right]$ adenosine into platelet membranes (12). Interaction of von Willebrand factor with platelets was studied indirectly by using ristocetin to induce platelet agglutination (13).

\section{METHODS}

Studies of platelet aggregation and secretion. Venous blood obtained from normal volunteers taking no medications was collected in plastic syringes and anticoagulated with $1 / 10$ vol of $0.13 \mathrm{M}$ trisodium citrate. Platelet-rich plasma and platelet-poor plasma were prepared by differential centrifugation (14), and the platelet count was adjusted to $3 \times 10^{8} / \mathrm{ml}$ with platelet-poor plasma. Platelet counts were performed with a Coulter counter model $\mathrm{Zb}$ equipped with a $50-\mu \mathrm{m}$ aperture tube (Coulter Electronics Inc., Hialeah, Fla.). Platelets in plasma were labeled with $\left[{ }^{14} \mathrm{C}\right]$ serotonin (15) and incubated at $25^{\circ} \mathrm{C}$, typically for $15 \mathrm{~min}$, with $1 / 10 \mathrm{vol}$ of various aqueous solutions of disodium carbenicillin (Roerig, Div. of Pfizer Pharmaceuticals, New York) or potassium penicillin G (buffer free; Squibb Institute, Princeton, N. J.). Control platelets were similarly incubated with $1 / 10$ vol of equimolar concentrations of sodium chloride (for carbenicillin) or potassium chloride (for penicillin) to control for the concentrations of cations in the antibiotic solutions. Platelet aggregation and $\left[{ }^{14} \mathrm{C}\right]$ serotonin release at $\mathrm{pH} 7.5$ were studied in response to (-)-epinephrine (Winthrop Laboratories, Sterling Drug Co., New York), or ADP (Sigma Chemical Co., St. Louis, Mo.) as previously described (14). To study the release of $\left[{ }^{14} \mathrm{C}\right]$ serotonin induced by the calcium ionophore, A23187 (Calbiochem-Behring Corp., American Hoechst Corp., San Diego, Calif.), platelets in plasma were labeled with $\left[{ }^{14} \mathrm{C}\right]$ serotonin, gel-filtered in Tyrode's-albumin buffer that contained $2 \mathrm{mM}$ EDTA (16), and stimulated with A23187 for $2 \mathrm{~min}$ at $37^{\circ} \mathrm{C}$. The release reaction was stopped by placing samples in an ice bath and then centrifuging samples at $4^{\circ} \mathrm{C}$ in preparation for counting ${ }^{14} \mathrm{C}$.

Alpha-adrenergic binding assays. Platelet-rich plasma was centrifuged at $2,000 \mathrm{~g}$ for $10 \mathrm{~min}$. The resulting platelet pellet was resuspended and washed twice at $16,000 \mathrm{~g}$ for 10 min at $4^{\circ} \mathrm{C}$ in an incubation buffer that contained $50 \mathrm{mM}$ Tris, $100 \mathrm{mM} \mathrm{NaCl}$, and $5 \mathrm{mM}$ EDTA, pH 7.4. Platelets were resuspended in the incubation buffer to a platelet count of $1.5 \times 10^{\%} / \mathrm{ml}$ and mixed with $1 / 10 \mathrm{vol}$ of an aqueous solution of either carbenicillin or penicillin $\mathrm{G}$, or with $\mathrm{NaCl}$ or $\mathrm{KCl}$ as controls. $\alpha$-adrenergic binding sites on intact platelets were quantitated as described previously $(17,18)$. Briefly, intact platelets $\left(3 \times 10^{8}\right.$ cells $)$ were incubated with $1 / 10 \mathrm{vol}$ of $\left.{ }^{3} \mathrm{H}\right]$ dihydroergocryptine $\left({ }^{3} \mathrm{H}-\mathrm{DHE}\right)^{1}(26-39 \mathrm{Ci} / \mathrm{mmol}$, New England Nuclear, Boston, Mass.) in duplicate $250 \mu \mathrm{l}$ aliquots at $37^{\circ} \mathrm{C}$ for $50 \mathrm{~min}$ in equilibrium studies and for various periods of time in kinetic studies. Binding reactions were stopped with $4 \mathrm{ml}$ incubation buffer that contained $10 \mu \mathrm{M}$ phentolamine at $37^{\circ} \mathrm{C}$. Samples were then filtered over glass fiber filters, and the filters were washed within $20 \mathrm{~s}$ with $20 \mathrm{ml}$ incubation buffer at $37^{\circ} \mathrm{C}(17,18)$. Nonspecific binding, determined by incubation of platelets simultaneously with ${ }^{3} \mathrm{H}$ DHE and $10 \mu \mathrm{M}$ phentolamine, accounted for $20-40 \%$ of the total amount of radioactive label bound. All data are presented as specific ${ }^{3} \mathrm{H}-\mathrm{DHE}$ binding, defined as total minus nonspecific binding. To monitor the stability of ${ }^{3} \mathrm{H}-\mathrm{DHE}$ in the presence of the antibiotics, ${ }^{3} \mathrm{H}-\mathrm{DHE}$ was incubated at $37^{\circ} \mathrm{C}$ with $50 \mathrm{mM}$ carbenicillin or penicillin for $2 \mathrm{~h}$. The radioligand

\footnotetext{
${ }^{1}$ Abbreviations used in this paper: ${ }^{3} \mathrm{H}-\mathrm{DHE},\left[{ }^{3} \mathrm{H}\right]$ dihydroergocryptine; epinephrine, (-)-epinephrine.
}

was extracted with ethanol and migrated identically as native ${ }^{3} \mathrm{H}$-DHE on thin-layer chromatography (18).

In experiments measuring the rate of dissociation of ${ }^{3} \mathrm{H}$ DHE from platelets, ${ }^{3} \mathrm{H}$-DHE $(2-4 \mathrm{nM})$ was incubated with platelets for $50 \mathrm{~min}$ at $37^{\circ} \mathrm{C}$ at which time $10 \mu \mathrm{M}$ phentolamine or a 100-fold excess of incubation buffer was added. Incubations were continued at $37^{\circ} \mathrm{C}$, and the amount of specific binding was determined at intervals for the next $60 \mathrm{~min}$. In all kinetic experiments, the concentration of ${ }^{3} \mathrm{H}-\mathrm{DHE}$ relative to that of the receptor was $>10: 1$.

It should be noted that platelet function studies with (-)epinephrine (epinephrine) were performed in plasma, whereas binding studies with ${ }^{3} \mathrm{H}$-DHE were performed in protein-free buffer. Nonetheless, it is assumed that at the antibiotic concentrations used, most of the antibiotic in plasma was not bound to protein (19).

5'-p-fluorosulfonylbenzoyl [3 H]adenosine incorporation into platelet membranes. Intact, gel-filtered platelets (16) or isolated platelet membranes $(20)$ were incubated with carbenicillin $(36-180 \mathrm{mM})$ or $\mathrm{NaCl}(72-360 \mathrm{mM})$ at $25^{\circ} \mathrm{C}$ for 15 min. $100 \mu \mathrm{M} 5$ '-p-fluorosulfonylbenzoyl [ ${ }^{3} \mathrm{H}$ ]adenosine in dimethylformamide was then added and the incubations were continued for an additional $15 \mathrm{~min}$ at $37^{\circ} \mathrm{C}$. The incorporation reaction was stopped by the addition of excess buffer at $4^{\circ} \mathrm{C}$ and the platelets or membranes were washed twice at $4^{\circ} \mathrm{C}$ (12). After washing, the intact, labeled platelets were lysed and their membranes isolated (20). Labeled membranes were dissolved in $10 \%$ sodium dodecyl sulfate, $0.2 \mathrm{M}$ dithiothreitol, and $8 \mathrm{M}$ urea and dialyzed for $12 \mathrm{~h}$ to remove unincorporated label. $300 \mu \mathrm{g}$ membrane protein was applied to $5 \%$ polyacrylamide, $0.1 \%$ sodium dodecyl sulfate disk gels. After electrophoresis, the gels were sliced, and the labeled proteins were eluted from the gel slices and counted for tritium (12).

Interaction of von Willebrand factor with platelets. Platelets in plasma were fixed in $1 \%$ formalin, washed, and resuspended to $5 \times 10^{8} / \mathrm{ml}$ in Tris-buffered saline (21). 1/10 vol of carbenicillin, penicillin $\mathrm{G}$, or control $\mathrm{NaCl}$ or $\mathrm{KCl}$ was added. Von Willebrand factor was assayed by a macroscopic agglutination method (22), with $0.1 \mathrm{ml}$ fixed, washed platelets, $0.1 \mathrm{ml}$ normal plasma pooled from 10 male donors, and 0.05 $\mathrm{ml}$ ristocetin $(0.8 \mathrm{mg} / \mathrm{ml}$ final concentration, Pacific Hemostasis Laboratories, Bakersfield, Calif.). In separate experiments, platelets were agglutinated with the snake venom from Bothrops neuwiedii $(0.62-40 \mu \mathrm{g} / \mathrm{ml}$ final concentration) (Sigma Chemical Co.) instead of ristocetin (23). Fixed platelets were also agglutinated with bovine factor VIII, using a bovine fibrinogen preparation $(0.06-4 \mathrm{mg} / \mathrm{ml}$ final concentration) (Sigma Chemical Co.) as the source of bovine factor VIII (24). Factor VIII antigen levels were quantitated by the Laurell quantitative immunoelectrophoretic technique as modified by Zimmerman et al. (25). Factor VIII coagulant activity was measured by a standard one-stage assay (26). Two separate experiments were performed to rule out a fluidphase interaction of von Willebrand factor and penicillin. First, sucrose density gradient ultracentrifugation of von Willebrand factor (human cryoprecipitate) and $\left[{ }^{14} \mathrm{C}\right]$ penicillin G (Amersham Corp., Arlington Heights, Ill.) was performed on a $10-40 \%$ continuous sucrose gradient by the method of Moore et al. (27). Amounts loaded onto $5 \mathrm{ml}$ gradients were: $250 \mu$ l of $\left[{ }^{14} \mathrm{C}\right]$ penicillin $\mathrm{G}\left(1 \times 10^{6} \mathrm{cpm} ; 31 \mathrm{mM}\right)$, and 250 $\mu l$ cryoprecipitate (100 $\mu \mathrm{g} / \mathrm{ml}$ factor VIII antigen). Second, potential binding of antibiotic to von Willebrand factor was assessed by gel filtration (28). $400 \mu$ l of phosphate-buffered saline (pH 7.4) that contained factor VIII antigen $(24.9 \mathrm{u} / \mathrm{ml})$ and $\left[{ }^{14} \mathrm{C}\right]$ penicillin $\left(10 \mathrm{mM} ; 4 \times 10^{4} \mathrm{cpm} / \mathrm{ml}\right)$ was applied to a $30 \times 0.8 \mathrm{~cm}$ Sephadex G-25 (course) column equilibrated with the buffer that contained $\left[{ }^{14} \mathrm{C}\right]$ penicillin. 
Platelet membrane fluidity. The fluidity of platelet membrane lipids was assessed with the hydrophobic fluorescent probe 1,6-diphenyl-1,3,5-hexatriene by measuring fluorescence polarization and calculating fluorescence anisotropy (29).

Statistics. Mean values are expressed \pm 1 SEM. The difference between means was examined by Student's $t$ test for paired or unpaired data. Equilibrium binding of ${ }^{3} \mathrm{H}-\mathrm{DHE}$ with platelets was analyzed by the method of Scatchard (30). The inhibition constant $\left(K_{i}\right)$ for epinephrine was calculated from the concentration of epinephrine that inhibited specific ${ }^{3} \mathrm{H}-\mathrm{DHE}$ binding by $50 \%$ (31). The association and dissociation rate constants for ${ }^{3} \mathrm{H}-\mathrm{DHE}$ binding to platelets were calculated as described by Newman et al. (11). Von Willebrand factor activity was determined by using log-log plots of percent plasma vs. platelet agglutination time (32).

\section{RESULTS}

Epinephrine-platelet interactions. Addition of carbenicillin or penicillin $\mathrm{G}(1-50 \mathrm{mM})$ to platelet-rich plasma resulted in the immediate inhibition of platelet function induced by $2 \mu \mathrm{M}$ epinephrine. Platelet function was inhibited whether measured as the initial rate of platelet aggregation, as the amplitude of aggregation or as $\left[{ }^{14} \mathrm{C}\right]$ serotonin release. The degree of inhibition was related to the concentration of antibiotic (Fig. 1). Carbenicillin inhibited the initial rate of aggregation half-maximally at $\sim 24 \mathrm{mM}$, the aggregation amplitude half-maximally at $17 \mathrm{mM}$ (Fig. 1 ), and $\left[{ }^{14} \mathrm{C}\right]-$ serotonin release half-maximally at $8 \mathrm{mM}$. Penicillin $\mathrm{G}$ was more potent than carbenicillin in that it inhibited the initial rate of aggregation half-maximally at $14 \mathrm{mM}$, the aggregation amplitude at $2.5 \mathrm{mM}$ (Fig. 1), and $\left[{ }^{14} \mathrm{C}\right]$ serotonin release at $2 \mathrm{mM}$. However, the inhibitory effects of each concentration of carbenicillin

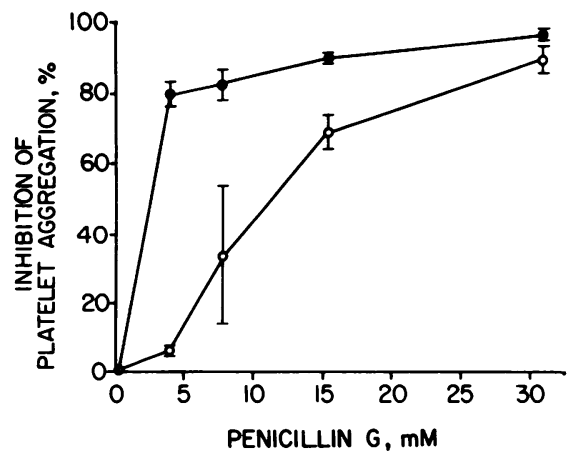

FIGURE 2 Effect of epinephrine concentration on the inhibition of platelet aggregation by penicillin G. Control platelets mixed with $\mathrm{KCl}$ and test platelets mixed with penicillin $\mathrm{G}$ were stimulated either by $2 \mu \mathrm{M}$ epinephrine (closed circles) or $40 \mu \mathrm{M}$ epinephrine (open circles). Data are plotted as the percent inhibition of the amplitude of aggregation of test platelets compared to controls and represent the means of four experiments.

or penicillin $\mathrm{G}$ could be reversed by increasing the concentration of epinephrine (Fig. 2).

Epinephrine initiates platelet function by binding to platelet $\alpha$-adrenergic receptors. Because carbenicillin and penicillin $G$ inhibited all phases of platelet function induced by epinephrine, we examined the effect of these antibiotics on platelet $\alpha$-adrenergic receptors by measuring the binding of the nonselective $\alpha$ adrenergic antagonist, ${ }^{3} \mathrm{H}$-DHE. ${ }^{3} \mathrm{H}$-DHE binds at equilibrium to a single class of binding sites on intact platelets and this binding demonstrates the saturability, high affinity, reversibility, and stereoselectivity char-

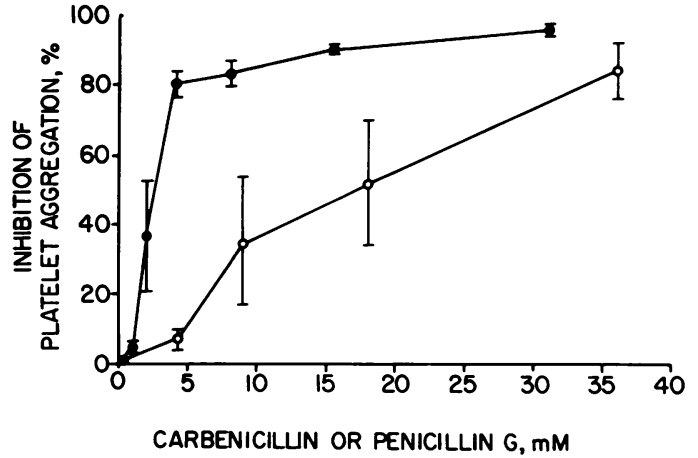

FIGURE 1 Inhibition of the amplitude of epinephrineinduced platelet aggregation by carbenicillin and penicillin G. Platelet-rich plasma was mixed with $2-72 \mathrm{mM} \mathrm{NaCl}$, as a control for carbenicillin, or $1-31 \mathrm{mM} \mathrm{KCl}$ as a control for penicillin G. Platelets were also mixed with 1-36 $\mathrm{mM}$ carbenicillin (open circles) or $1-31 \mathrm{mM}$ penicillin $\mathrm{G}$ (closed circles). They were then stimulated with $2 \mu \mathrm{M}$ epinephrine and this resulted in complete aggregation of control platelets. Data are plotted as the percent inhibition of the amplitude of aggregation of test platelets compared to the aggregation amplitude of control platelets. Data are the mean \pm SEM of four experiments.

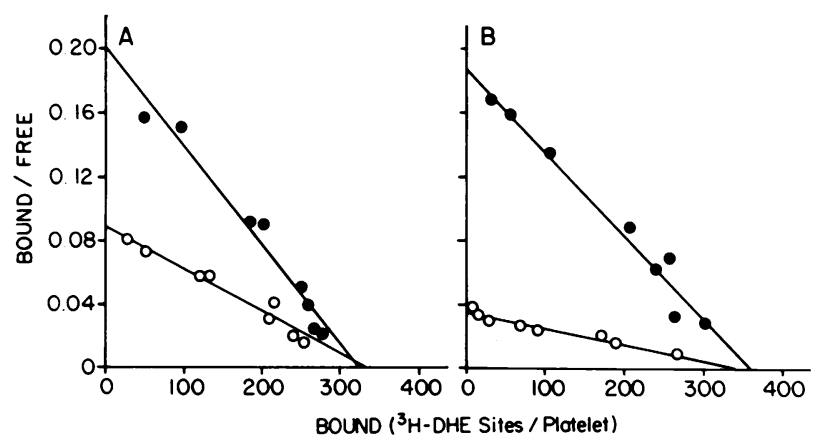

FIGURE 3 Scatchard analysis of equilibrium binding of $\left[{ }^{3} \mathrm{H}\right]-$ dihydroergocryptine to platelets: effect of carbenicillin and penicillin G. Closed circles depict control platelets and open circles depict platelets incubated with $36 \mathrm{mM}$ carbenicillin (A) or $31 \mathrm{mM}$ penicillin G (B). The lines were calculated from the data by the method of least squares. The intercept of each line on the ordinate indicates the maximum number of ${ }^{3} \mathrm{H}$-DHE binding sites per platelet and the slope of each line depicts the dissociation constant $\left(K_{\mathrm{d}}\right)$ for equilibrium binding. The $K_{\mathrm{d}}$ for control platelets was $4.0 \mathrm{nM}$ (A) and $4.1 \mathrm{nM}$ (B). The $K_{\mathrm{d}}$ for carbenicillin-treated platelets was $9.5 \mathrm{nM}$, whereas that for penicillin-treated platelets was $20.2 \mathrm{nM}$. Data from several such experiments are summarized in Table I. 
TABLE I

Effect of Carbenicillin and Penicillin $G$ on the Equilibrium Binding of $\left[{ }^{3} \mathrm{H}\right]$ Dihydroergocryptine to Human Platelets

\begin{tabular}{lccc}
\hline & & $\begin{array}{c}{ }^{3} \mathrm{H}-\mathrm{DHE} \\
\text { dissociation } \\
\text { constant }\end{array}$ & $\begin{array}{c}\text { Epinephrine } \\
\text { inhibition } \\
\text { constant }\end{array}$ \\
\hline & sites/platelet & $n M$ & $\mu M$ \\
$\begin{array}{c}\text { Control (9)* } \\
\text { Carbenicillin, } \\
36 \mathrm{mM}(5)^{*}\end{array}$ & $405 \pm 21$ & $4.1 \pm 0.4$ & $5.9 \pm 0.6$ \\
$\begin{array}{c}\text { Penicillin G, } \\
31 \mathrm{mM} \mathrm{(4)*}\end{array}$ & $394 \pm 36$ & $25.6 \pm 5.5$ & $35.4 \pm 13.9$ \\
\hline
\end{tabular}

* Number of experiments performed.

acteristic of the $\alpha$-adrenergic receptor $(11,17,18)$. At concentrations of antibiotic that inhibited epinephrineinduced platelet function by more than $80 \%$, carbenicillin $(36 \mathrm{mM})$ and penicillin $\mathrm{G}(31 \mathrm{mM})$ did not change the maximum number of ${ }^{3} \mathrm{H}$-DHE binding sites per platelet (Fig. 3, Table I). In contrast, these antibiotics decreased significantly the apparent affinity of platelet $\alpha$-adrenergic receptors for ${ }^{3} \mathrm{H}$-DHE. Thus, the dissociation constant $\left(K_{\mathrm{d}}\right)$ for ${ }^{3} \mathrm{H}$-DHE was twofold higher than normal in the presence of carbenicillin $(P<0.01)$ and sixfold higher than normal in the presence of penicillin $\mathrm{G}(P<0.01)$ (Fig. 3 and Table I). With a single concentration of ${ }^{3} \mathrm{H}$-DHE ( $\left.2 \mathrm{nM}\right)$, an effect on the specific binding of ${ }^{3} \mathrm{H}$-DHE was observed at a carbenicillin concentration as low as $5 \mathrm{mM}$ and at a penicillin $\mathrm{G}$ concentration as low as $1 \mathrm{mM}$.

The effect of penicillin $\mathrm{G}$ on the dissociation constant for ${ }^{3} \mathrm{H}$-DHE in these equilibrium studies was confirmed in independent kinetic experiments. The dissociation rate constant $\left(k_{2}\right)$ of ${ }^{3} \mathrm{H}-\mathrm{DHE}$ was decreased only slightly by penicillin $\mathrm{G}(31 \mathrm{mM})$, whereas the association rate constant $\left(k_{1}\right)$ was decreased markedly by penicillin G (Table II). Therefore, the resultant $K_{d}$ $\left(k_{2} / k_{1}\right)$ was increased significantly by penicillin $G$ (control: $3.4 \pm 0.6 \mathrm{nM}$; penicillin G: $9.6 \pm 1.3 \mathrm{nM}$; $P<0.01)$.

TABLE II

Effect of Penicillin G on the Kinetic Constants of $\left[{ }^{3} \mathrm{H}\right]$ Dihydroergocryptine Binding to Platelets

\begin{tabular}{cccc}
\hline & $\begin{array}{c}\text { Association rate } \\
\text { constant }\end{array}$ & $\begin{array}{c}\text { Dissociation } \\
\text { rate constant }\end{array}$ & $\begin{array}{c}\text { Dissoci- } \\
\text { ation } \\
\text { constant }\end{array}$ \\
\hline & $M^{-1} \min ^{-1}$ & $\min ^{-1}$ & $n M$ \\
Control (6)* & $1.16 \pm 0.17 \times 10^{7}$ & $0.034 \pm 0.002$ & $3.4 \pm 0.6$ \\
$\begin{array}{c}\text { Penicillin G, } \\
31 \mathrm{mM}(6)^{*}\end{array}$ & $0.28 \pm 0.02 \times 10^{7}$ & $0.028 \pm 0.002$ & $9.6 \pm 1.3$ \\
\hline
\end{tabular}

* Number of experiments performed.
The studies described above document the effects of carbenicillin and penicillin $G$ on the binding of an $\alpha$-adrenergic antagonist to the platelet, but they do not address the issue as to whether these antibiotics affect the binding of the $\alpha$-adrenergic agonist, epinephrine. Therefore, the affinity of epinephrine for platelet $\alpha$-adrenergic receptors was assessed by determining the potency with which epinephrine competed for ${ }^{3} \mathrm{H}$-DHE binding sites (31). Just as with ${ }^{3} \mathrm{H}$-DHE itself, the binding affinity of ${ }^{3} \mathrm{H}$-DHE sites for epinephrine was decreased twofold by carbenicillin $(P<0.02)$ and sixfold by penicillin $\mathrm{G}(P<0.001)$ (Table I). Thus, the binding of ${ }^{3} \mathrm{H}$-DHE and epinephrine to platelet $\alpha$ adrenergic receptors was competitively inhibited by concentrations of antibiotic that competitively inhibited epinephrine-induced platelet aggregation and $\left[{ }^{14} \mathrm{C}\right]$ serotonin release. Penicillin $G$ was more potent than carbenicillin both in inhibiting the binding of the agonist and in inhibiting platelet function. The inhibitory effects of these antibiotics on platelet function and binding could be reversed either by a single washing of platelets or by gel filtration in antibiotic-free buffer (data not shown).

ADP-platelet interactions. Carbenicillin inhibited the initial rate of ADP-induced $(2 \mu \mathrm{M})$ platelet aggregation half-maximally at $26 \mathrm{mM}$, the aggregation amplitude half-maximally at $14 \mathrm{mM}$, and $\left[{ }^{14} \mathrm{C}\right]$ serotonin release half-maximally at $2 \mathrm{mM}$. Inhibition could be reversed by increasing the concentration of ADP 20fold (Fig. 4).

The ADP affinity analogue, 5'-p-fluorosulfonylbenzoyl $\left[{ }^{3} \mathrm{H}\right]$ adenosine, inhibits ADP-induced platelet shape change as it is incorporated into a $100,000 \mathrm{~mol} \mathrm{wt}$ polypeptide on the surface membrane of human platelets (12). Incorporation of this analogue is inhibited by ADP or ATP but not by other nucleotides or aggregating agents (12). Because many of the features of incorpora-

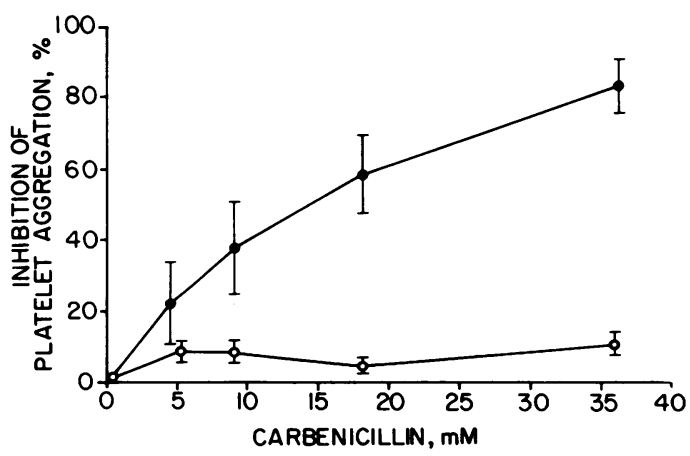

FIGURE 4 Effect of ADP concentration on the inhibition of platelet aggregation by carbenicillin. Control platelets mixed with $\mathrm{NaCl}$ and test platelets mixed with carbenicillin were stimulated either by $2 \mu \mathrm{M}$ ADP (closed circles) or $40 \mu \mathrm{M}$ ADP (open circles). Data are plotted as the percent inhibition of the amplitude of aggregation of test platelets compared to controls and represent the means of four experiments. 


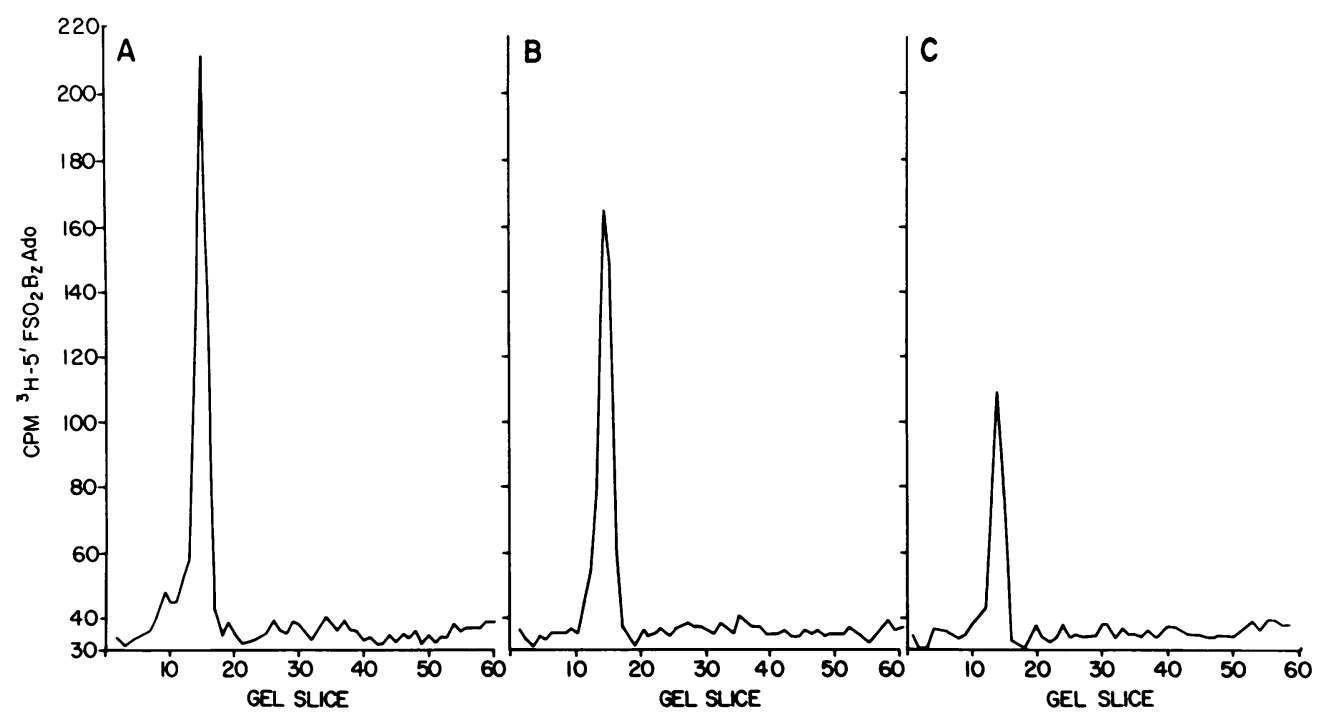

FIGURE 5 Inhibition by carbenicillin of incorporation of the ADP affinity analogue, $5^{\prime}$-p -fluorosulfonylbenzoyl $\left[{ }^{3} \mathrm{H}\right]$ adenosine, into membranes of intact platelets. Intact platelets were mixed with 72-360 mM NaCl (A) or carbenicillin ( $36 \mathrm{mM}, \mathrm{B} ; 180 \mathrm{mM} \mathrm{C}$ ), then incubated with $100 \mu \mathrm{M}$ of the ADP affinity analogue as described in Methods. Platelets were washed and fractionated and solubilized membranes ( $300 \mu \mathrm{g}$ protein) were applied to a $0.1 \%$ sodium dodecyl sulfate, $5 \%$ polyacrylamide gel and electrophoresed. The single membrane polypeptide labeled in control platelets as well as that labeled progressively less well in the presence of increasing amounts of carbenicillin had an apparent mol wt of 100,000 (12).

tion of this analogue into the $100,000 \mathrm{~mol}$ wt membrane polypeptide fulfill the requirements for the putative ADP receptor, it is possible that this polypeptide may be the receptor. To localize the site of action of carbenicillin to the platelet surface, gel-filtered platelets were incubated with carbenicillin for 15 min followed by the addition of the ADP analogue and incubation for a further $15 \mathrm{~min}$. The extent of incorporation of the ADP analogue into the $100,000 \mathrm{~mol}$ wt membrane polypeptide was decreased (Fig. 5). When the ADP analogue is incubated with isolated platelet membranes rather than intact platelets, it is incorporated into four polypeptides, one of which is the $100,000 \mathrm{~mol}$ wt polypeptide (12). When isolated membranes were incubated with carbenicillin and the ADP analogue, incorporation of the analogue into all four membrane polypeptides was decreased.

Von Willebrand factor-platelet interactions. Von Willebrand factor binds to platelets in vitro upon the addition of ristocetin (33), and this results in platelet agglutination (13). The effect of carbenicillin and penicillin $G$ on the interaction of von Willebrand factor with its platelet receptor was determined by measuring ristocetin-induced platelet agglutination in the presence of several concentrations of the antibiotics. Platelet agglutination induced by ristocetin $(0.8 \mathrm{mg} / \mathrm{ml})$ was inhibited by penicillin $G$ in a concentration-dependent manner, and this effect was observed at a penicillin concentration as low as $0.6 \mathrm{mM}$ (Figs. 6 and 7). Simi- larly, carbenicillin decreased ristocetin-induced platelet agglutination at a carbenicillin concentration as low as $2.6 \mathrm{mM}$. These inhibitory effects could be overcome by increasing the concentration of ristocetin. Von Willebrand factor also is known to mediate the platelet agglutination stimulated by certain snake venoms (23) or by bovine factor VIII alone (24). Carbenicillin and penicillin $\mathrm{G}$ inhibited platelet agglutination either in the presence of human plasma plus venom from the snake, Bothrops neuwiedii, or in the presence of bovine factor VIII alone (data not shown).

Three experiments were performed to exclude an interaction of von Willebrand factor with penicillin $\mathrm{G}$ or carbenicillin, independent of platelets. First, each antibiotic $(36 \mathrm{mM})$ was incubated with normal pooled plasma for $30 \mathrm{~min}$ at $37^{\circ} \mathrm{C}$. Neither antibiotic inhibited factor VIII coagulant activity or the level of factor VIII antigen present in this plasma. Second, $\left[{ }^{14} \mathrm{C}\right]$ penicillin and von Willebrand factor (assessed by measurement of factor VIII antigen) were subjected to sucrose density gradient ultracentrifugation. $\left[{ }^{14} \mathrm{C}\right]$ Penicillin added onto the gradient alone equilibrated at the top of the gradient, whereas factor VIII antigen added alone equilibrated near the bottom. Their location on the gradient was unaffected by the prior addition of ristocetin $(0.8 \mathrm{mg} / \mathrm{ml})$ or by preincubation of the $\left[{ }^{14} \mathrm{C}\right]$ penicillin $\mathrm{G}$ with the factor VIII antigen before their addition onto the gradient. Third, no binding of $\left[{ }^{14} \mathrm{C}\right]$ penicillin to factor VIII antigen was detected after gel filtration on Sephadex 


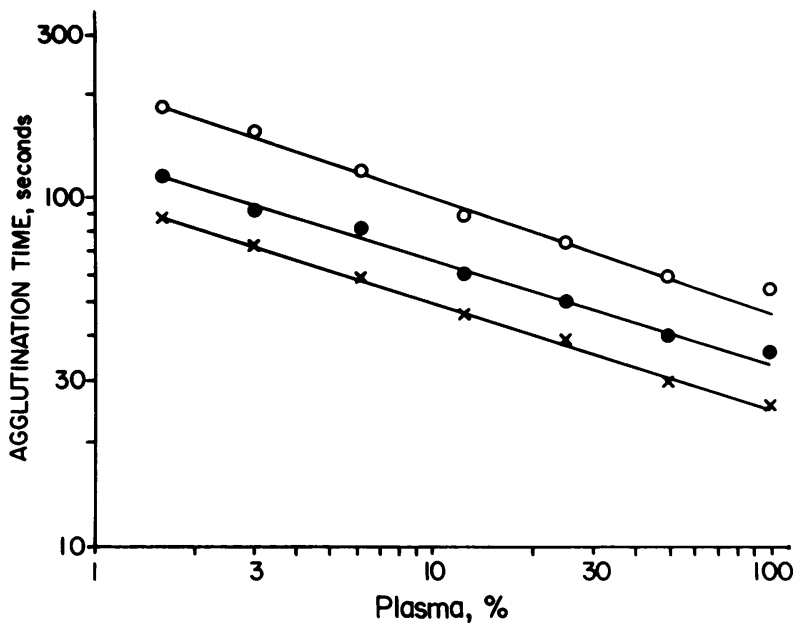

FIGURE 6 Inhibition of ristocetin-induced platelet agglutination by penicillin $\mathrm{G}$. In this example, control platelets were mixed with $31 \mathrm{mM} \mathrm{KCl}$ (bottom line) and test platelets were mixed with $0.6 \mathrm{mM}$ penicillin $\mathrm{G}$ (closed circles) or with $32 \mathrm{mM}$ penicillin $\mathrm{G}$ (open circles). The platelets were then added to various dilutions of pooled normal plasma as a source of von Willebrand factor and then stimulated with $0.8 \mathrm{mg} / \mathrm{ml}$ ristocetin. The data are plotted as the agglutination time of platelets versus the percent of normal pooled plasma. For any given amount of plasma (von Willebrand factor), the amount of time required for platelets to agglutinate was increased in the presence of penicillin $G$.

G-25. Thus, inhibition of ristocetin-induced platelet agglutination by these antibiotics appears to occur at the platelet surface rather than in the fluid phase.

Effects of carbenicillin and penicillin $G$ on platelet membranes. Neither carbenicillin nor penicillin $\mathrm{G}$ is strongly lipophilic (19). However, penicillin $G$ is more potent than carbenicillin in inhibiting platelet function

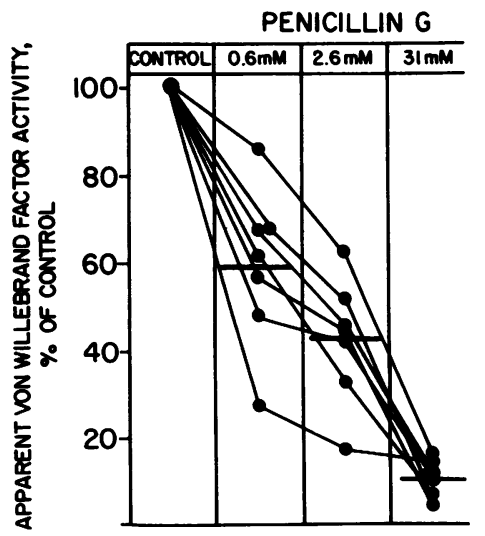

FIGURE 7 Effect of penicillin G on apparent von Willebrand factor activity. Apparent von Willebrand activity was quantitated from curves such as those shown in Fig. 5 (32). Each experimental curve was compared to a control curve generated on the same day. The von Willebrand factor activity of control platelets varied less than $10 \%$ from day to day. and agonist binding, and it is more lipophilic than carbenicillin (19). The interaction of lipophilic compounds with membrane lipids can be monitored by hydrophobic fluorescent probes (34). The fluidity of the platelet membrane lipid bilayer was assessed by labeling membranes with the fluorescent probe, 1,6diphenyl-1,3-5-hexatriene, to see whether either of the antibiotics interacted with membrane lipids. In three experiments, neither antibiotic (1-50 mM) affected the fluorescence anisotropy of this probe within platelet membranes, whether measured at $10^{\circ}, 25^{\circ}$, or $37^{\circ} \mathrm{C}$.

The platelet release reaction is believed to be mediated by calcium ion fluxes between platelet membranes and intracellular, nonmembranous cell components. Such calcium ion fluxes and serotonin release can be stimulated directly by the calcium ionophore, A23187. To test whether carbenicillin or penicillin $\mathrm{G}$ had inhibitory effects in addition to their effects on the binding of agonists, the release of $\left[{ }^{14} \mathrm{C}\right]$ serotonin by gel filtered platelets in response to A23187 was studied. These studies were carried out in Tyrode's-albumin buffer in the presence of $2 \mathrm{mM}$ EDTA and without stirring to prevent platelet aggregation. When present in concentrations that had inhibited epinephrine or ADP-induced serotonin release by $70-100 \%$, neither antibiotic inhibited ionophore-induced $\left[{ }^{14} \mathrm{C}\right]$ serotonin release (Table III).

\section{DISCUSSION}

These studies demonstrate that both carbenicillin and penicillin $\mathrm{G}$ impair the interaction of several platelet agonists with their specific receptors on the platelet membrane. In the case of epinephrine, direct radioligand binding studies demonstrate that these antibiotics cause a reduction in the apparent affinity of platelet $\alpha$-adrenergic receptors for ${ }^{3} \mathrm{H}$-DHE and for epinephrine. In the case of ADP, carbenicillin inhibits the covalent incorporation of an ADP affinity analogue, $5^{\prime}$ - $p$-fluorosulfonylbenzoyl $\left[{ }^{3} \mathrm{H}\right]$-adenosine, into a platelet membrane polypeptide which may be the ADP receptor. In both cases, the concentrations of antibiotic that inhibit binding also inhibit platelet aggregation and serotonin release. In addition, carbenicillin and penicillin $G$ appear to inhibit the interaction of von Willebrand factor with the platelet surface, whether this interaction is stimulated by ristocetin or by venom from the snake, Bothrops neuwiedii. Taken together, these data are consistent with the concept that impairment of the interaction of agonists with the platelet surface is causative of the platelet function abnormalities produced by these antibiotics in vitro.

The mechanism(s) whereby these antibiotics inhibit the binding of agonists to the platelet surface is not clear. The ADP receptor may be a surface membrane glycoprotein with a mol wt of $100,000(12)$, whereas the 
TABLE III

Effect of Carbenicillin and Penicillin G on A23187-induced $\left[{ }^{14} \mathrm{C}\right]$ Serotonin Release from Gel-filtered Platelets

\begin{tabular}{ccccc}
\hline & \multicolumn{5}{c}{${ }^{\left[{ }^{4} \mathrm{C}\right] \text { Serotonin release }}$} \\
\cline { 2 - 5 } $\mathrm{A} 23187$ & $\begin{array}{c}\text { Carbenicillin } \\
(36 \mathrm{mM})\end{array}$ & $\begin{array}{c}\mathrm{NaCl} \\
(72 \mathrm{mM})\end{array}$ & $\begin{array}{c}\text { Penicillin } \mathrm{G} \\
(3 \mathrm{mM})\end{array}$ & $\begin{array}{c}\mathrm{KCl} \\
(3 \mathrm{mM})\end{array}$ \\
\hline$\mu M$ & \multicolumn{5}{c}{$\%$} \\
0.1 & $0.7^{*}$ & 1.0 & 0.2 & 0 \\
0.5 & 8.4 & 5.0 & 3.0 & 2.2 \\
1.0 & 27.0 & 21.8 & 11.0 & 9.2 \\
2.5 & 46.2 & 35.0 & 21.0 & 18.7 \\
5.0 & 50.8 & 53.8 & 41.0 & 39.7 \\
10.0 & 58.0 & 69.2 & 51.0 & 60.0 \\
\hline
\end{tabular}

* Mean of four experiments.

platelet receptor for von Willebrand factor appears to be a glycoprotein of mol wt 150,000 (35). The platelet membrane component that binds epinephrine has not yet been characterized. Thus, receptors for agonists appear to include several different proteins or glycoproteins that are presumably embedded within the membrane's lipid bilayer and also exposed, in part, to the platelet's aqueous exterior. Theoretically, carbenicillin $\mathrm{G}$ might interfere with the binding of agonists to their receptors by interacting directly with these membrane proteins or by interacting with the lipid milieu in which these proteins are embedded (36).

Penicillin and carbenicillin are known to bind either covalently or reversibly to several bacterial membrane proteins (37). No information is available as to whether these antibiotics bind to the platelet. However, if they do bind to the platelet membrane, their binding affinity must be very low because washing or gel filtration of platelets reverses their inhibitory effects. Penicillin is also known to interact hydrophobically with artificial phospholipid bilayers (38). Thus, it could associate with platelet membrane lipids. In fact, penicillin, which is more lipid soluble than carbenicillin (19), was more inhibitory of platelet function as well. Neither antibiotic affected bulk platelet membrane lipid fluidity as determined by fluorescence polarization of a hydrophobic probe. However, a negative result with the fluorescent probe, which reports on the average motion of all membrane lipids, does not totally exclude a more localized yet significant interaction of the antibiotics with membrane lipids.

The decrease in apparent affinity of alpha adrenergic receptors for ${ }^{3} \mathrm{H}-\mathrm{DHE}$ in the presence of penicillin appears to be explained by a slower rate of association of ${ }^{3} \mathrm{H}-\mathrm{DHE}$ with the receptor, rather than an increased rate of dissociation of the ligand from the receptor. A similar change has been reported in the kinetics of binding of insulin to its receptors on cultured human lymphocyte membranes in the presence of the membrane perturbant, dimethyl sulfoxide (39).

Little is known concerning the sequence of cellular events that follows agonist binding and results in platelet aggregation and secretion. The synthesis of prostaglandin endoperoxides and thromboxane $A_{2}$, as well as internal calcium shifts within the platelet appear to play a role $(40,41)$. An effect of carbenicillin or penicillin $\mathrm{G}$ on agonist binding does not exclude other potential mechanisms of platelet inhibition distal to binding. However, Johnson and co-workers (42) have reported that carbenicillin does not affect platelet prostaglandin synthesis and that it inhibits platelets by a mechanism different than aspirin. In this study, platelet $\left[{ }^{14} \mathrm{C}\right]$ serotonin release induced by the calcium ionophore, A23107, was not inhibited by carbenicillin or penicillin G. This suggests that a mechanism of inhibition unrelated to the process of internal calcium shifts.

There are two important differences between the inhibition of platelet function observed with these antibiotics in vitro and that observed in vivo. First, these antibiotics inhibit platelets immediately in vitro, whereas they appear to prolong the bleeding time only after $12-24 \mathrm{~h}$ of parenteral administration (2-4). Second, the peak serum concentration of either antibiotic achieved when high doses are given to man $(1 \mathrm{mM})$ is several-fold lower than that necessary to inhibit platelet aggregation and secretion in vitro (Figs. 1 and 4). Therefore in man, either prolonged contact of platelets with lower concentrations of antibiotic or a metabolite of the antibiotic may be necessary for inhibition. Whatever the reason for these differences, the pattern of functional platelet abnormalities in individuals receiving carbenicillin or penicillin $G$ is similar to the pattern produced in vitro: inhibition of the platelet aggregation and secretion induced by several agonists, this inhibition being reversed by larger concentrations of agonist. Nonetheless, the present in vitro studies do not directly establish the mechanism of platelet inhibition for these antibiotics in vivo.

The demonstration that ristocetin-induced platelet agglutination is decreased by these antibiotics in vitro suggests that impaired interaction of this plasma protein with the platelet might account, in part, for the prolonged bleeding time produced by these drugs. Indeed, we have confirmed the report of Andrassy et al. (2) demonstrating decreased ristocetin-induced platelet agglutination associated with prolonged bleeding times in several patients receiving large doses of carbenicillin or penicillin G. ${ }^{2}$ It is recognized that the process of ristocetin-induced platelet agglutination does not necessarily reflect the complex process of von Willebrand factor-platelet-subendothelium interaction in vivo (43).

${ }^{2}$ Shattil, S. J. Unpublished observations. 
Nonetheless, impairment of such interaction by carbenicillin or penicillin $\mathrm{G}$ could explain the reported antithrombotic activity of these antibiotics in dogs (44, $45)$ as well as the failure of penicillin-treated platelets to correct the bleeding time of thrombocytopenic rabbits (46).

\section{ACKNOWLEDGMENTS}

The authors are grateful to Mrs. Patricia A. Lafferty for typing the manuscript.

This work was supported in part by Research funds from the U. S. Veterans Administration, by grants-in-aid from the American Heart Association, and by a grant (HL-18827) from the National Institutes of Health.

\section{REFERENCES}

1. Haburchak, D. R., D. R. Head, and E. D. Everett. 1977. Postoperative hemorrhage associated with carbenicillin administration-report of two cases and review of the literature. Am. J. Surg. 134: 630-634.

2. Andrassy, K., E. Ritz, B. Hasper, M. Scherz, E. Walter, H. Storch, and W. Vömel. 1976. Penicillin-induced coagulation disorder. Lancet. II: 1039-1041.

3. Brown, C. H., E. A. Natelson, W. Bradshaw, T. W. Williams, and C. P. Alfrey. 1974. The hemostatic defect produced by carbenicillin. N. Engl.J. Med. 291: 265-270.

4. Lacombe, M. J., B. Varet, P. Godeau, G. Herreman, and A. Cenac. 1974. Action de fortes doses de pénicillin G sur les plaquettes. Nouv. Presse Med. 3: 1435-1437.

5. Cazenave, J. P., M. A. Packham, M. A. Guccione, and J. F. Mustard. 1973. Effects of penicillin G on platelet aggregation, release and adherence to collagen. Proc. Soc. Exp. Biol. Med. 142: 159-166.

6. Mills, D. C. B., and D. E. Macfarlane. 1976. Platelet receptors. In Platelets in Biology and Pathology. G. L. Gordon, editor. Elsevier/North Holland, Amsterdam. 159-201.

7. Majerus, P. W., and J. P. Miletich. 1978. Relationships between platelets and coagulation factors in hemostasis. Annu. Rev. Med. 29: 41-49.

8. Tschopp, T. B., H. J. Weiss, and H. R. Baumgartner. 1974. Decreased adhesion of platelets to subendothelium in von Willebrand's disease. J. Lab. Clin. Med. 83: 296300 .

9. O'Brien, J. R. 1963. Some effects of adrenaline and antiadrenaline compounds on platelets in vitro and in vivo. Nature (Lond.). 200: 763-764.

10. Mills, D. C. B., and G. C. K. Roberts. 1967. Effects of adrenaline on human blood platelets. J. Physiol. 193: 443-453.

11. Newman, K. D., L. T. Williams, N. H. Bishopric, and R. J. Lefkowitz. 1978. Identification of $\alpha$-adrenergic receptors in human platelets by $\left[{ }^{3} \mathrm{H}\right]$ dihydroergocryptine binding. J. Clin. Invest. 61: 395-402.

12. Bennett, J. S., R. F. Colman, and R. W. Colman. 1978. Identification of adenine nucleotide binding proteins in human platelet membranes by affinity labeling with 5 'p-fluorosulfonylbenzoyl ${ }^{3} \mathrm{H}$-adenosine. J. Biol. Chem. 253: 7346-7354.

13. Howard, M. A., and B. G. Firkin. 1971. Ristocetin-a new tool in the investigation of platelet aggregation. Thromb. Diath. Haemorrh. 26: 362-369.

14. Shattil, S. J., R. Anaya-Galindo, J. Bennett, R. W. Colman, and R. A. Cooper. 1975. Platelet hypersensitivity induced by cholesterol incorporation. J. Clin. Invest. 55: $636-643$.

15. Jerushalmy, Z., and M. B. Zucker. 1966. Some effects of fibrinogen degradation products (FDP) on blood platelets. Thromb. Diath. Haemorrh. 15: 413-419.

16. Tangen, O., H. J., Berman, and P. Marfey. 1971. Gel filtration: a new technique for separation of blood platelets from plasma. Thromb. Diath. Haemorrh. 25: 268-278.

17. Kaywin, P., M. McDonough, P. A. Insel, and S. J. Shattil. 1978. Platelet function in essential thrombocythemia-decreased epinephrine responsiveness associated with a deficiency of platelet $\alpha$-adrenergic receptors. $N$. Engl. J. Med. 299: 505-509.

18. Insel, P. A., P. Nirenberg, J. Turnbull, and S. J. Shattil. 1978. Relationship between membrane cholesterol, $\alpha$ adrenergic receptors and platelet function. Biochemistry. 17: 5269-5274.

19. Bergan, T. 1978. Penicillins. Antibiot. Chemother. (Wash. D. C.). 25: 1-122.

20. Barber, A. J., and G. A. Jamieson. 1970. Isolation and characterization of plasma membranes from human platelets. J. Biol. Chem. 245: 6359-6365.

21. Macfarlane, D. E., J. Stibbe, E. P. Kirby, M. B. Zucker, R. A. Grant, and J. McPherson. 1975. A method for assaying von Willebrand factor (ristocetin cofactor). Thromb. Diath. Haemorrh. 34: 306-308.

22. Brinkhous, K. M., J. E. Graham, H. A. Cooper, J. P. Allain, and R. H. Wagner. 1975. Assay of von Willebrand factor in von Willebrand's disease and hemophilia: use of a macroscopic platelet aggregation test. Thromb. Res. 6: $267-272$.

23. Read, M. S., R. W. Shermer, and K. M. Brinkhous. 1978. Venom coagglutinin: an activator of platelet aggregation dependent on von Willebrand factor. Proc. Natl. Acad. Sci.U.S. A. 75: 4514-4518.

24. Kirby, E. P., and D. C. B. Mills. 1975. The interaction of bovine factor VIII with human platelets.J. Clin. Invest. 56: 491-502.

25. Zimmerman, T. S., O. D. Ratnoff, and A. E. Powell. 1971. Immunologic differentiation of classic hemophilia (factor VIII deficiency) and von Willebrand's disease. J. Clin. Invest. 50: 244-254.

26. Hardisty, R. H., and J. C. McPherson. 1962. One stage factor AHG assay and its uses, venous and capillary. Thromb. Diath. Haemorrh. 7: 215-226, 1962.

27. Moore, A., G. D. Ross, and R. L. Nachman. 1978. Interaction of platelet membrane receptors with von Willebrand factor, ristocetin, and the $\mathrm{F}_{\mathrm{c}}$ region of immunoglobulin $\mathrm{G}$. J. Clin. Invest. 62: 1053-1060.

28. Hummel, J. P., and W. J. Dreyer. 1962. Measurement of protein-binding phenomena by gel filtration. Biochim. Biophys. Acta. 63: 530-532.

29. Shattil, S. J., and R. A. Cooper. 1976. Membrane microviscosity and human platelet function. Biochemistry. 15: 4832-4837.

30. Scatchard, G. 1949. The attractions of proteins for small molecules and ions. Ann. N. Y. Acad. Sci. 51: 660-672.

31. Cheng, Y., and W. H. Prusoff. 1973. Relationship between the inhibition constant $\left(\mathrm{K}_{\mathrm{i}}\right)$ and the concentration of inhibitor which causes 50 percent inhibition $\left(\mathrm{I}_{50}\right)$ of an enzymatic reaction. Biochem. Pharmacol. 22: 3099-3108.

32. Weiss, H. J., L. W. Hoyer, F. R. Rickles, A. Varma, and J. Rogers. 1973. Quantitative assay of a plasma factor, deficient in von Willebrand's disease, that is necessary for platelet aggregation. J. Clin. Invest. 52: 2708-2716.

33. Kao, K.-J., S. U. Pizzo, and P. A. McKee. 1979. Demonstration and characterization of specific binding sites for 
factor VIII/von Willebrand factor on human platelets. J. Clin. Invest. 63: 656-664.

34. Feinstein, M. B., S. M. Fernandez, and R. I. Sha'afi. 1975. Fluidity of natural membranes and phosphatidylserine and ganglioside dispersions. Effects of local anesthetics, cholesterol and protein. Biochim. Biophys. Acta. 413: 354-370.

35. Nurden, A. T., and J. P. Caen. 1976. Role of surface glycoproteins in human platelet function. Thromb. Haemostasis. 35: 139-150.

36. Shattil, S. J., and R. A. Cooper. 1978. Role of membrane lipid composition, organization, and fluidity in human platelet function. In Progress in Hemostasis and Thrombosis. T. H. Spaet, editor. Grune \& Stratton, Inc., New York. 4: 59-86.

37. Spratt, B. G. 1977. Properties of the penicillin-binding proteins of Escherichia coli K12. Eur. J. Biochem. 72: 341-352.

38. Padfield, J. M., and I. W. Kellaway. 1973. Rheological studies on mixed phospholipid sols and their interaction with penicillins. I. Continuous shear viscometry. Chem. Phys. Lipids. 10: 356-368.

39. Van Obbergheu, E., P. DeMeyts, and J. Roth. 1979. Inhibition of insulin receptor binding by dimethyl sulfoxide. Biochim. Biophys. Acta. 582: 486-495.
40. Marcus, A. J. 1978. The role of lipids in platelet function: with particular reference to the arachidonic acid pathway. J. Lipid Res. 19: 793-826.

41. Detwiler, T. C., I. F. Charo, and R. O. Feinman. 1978. Evidence that calcium regulates platelet function. Thromb. Haemostasis. 40: 207-211.

42. Johnson, G. J., L. A. Leis, G. H. R. Rao, and J. G. White. 1978. Prostaglandin synthesis remains intact in nonaggregating carbenicillin treated platelets. Circulation. 58: II- 125 .

43. Ruggeri, Z. M., F. I. Pareti, P. M. Manucci, and T. S. Zimmerman. 1979. Increased ristocetin induced binding of factor VIII to platelets in von Willebrand's disease. Clin. Res. 27: 464A. (Abstr.)

44. Johnson, G. J., H. R. Gundu, and J. G. White. 1978. Platelet dysfunction induced by parenteral carbenicillin and ticarcillin. Am. J. Pathol. 91: 85-106.

45. Lyman, B. T., G. J. Johnson, and J. G. White. 1978. Dose-dependent inhibition of experimental arterial thrombosis by carbenicillin and ticarcillin. Am. J. Pathol. 92: 473-485.

46. Cazenave, J.-P., H.-J. Reimers, A. F. Senyi, J. Hirsh, M. A. Packham, and J. F. Mustard. 1976. Effects of penicillin $\mathrm{G}$ and cephalothin on platelet function in vivo. Proc. Soc. Exp. Biol. Med. 152: 641-644. 